\title{
PROBIOTIK MENINGKATKAN KONSENTRASI HEMOGLOBIN PADA TIKUS PUTIH YANG DIINDUKSI LIPOPOLISAKARIDA ESCHERICHIA COLI
}

\author{
Efris Kartika Sari凶${ }^{\star 凶}$, Titin Andri Wihastuti ${ }^{\star}$, Wahyu Ardiansyah*
}

\begin{abstract}
Abstrak
Infeksi bakteri Escherichia coli (E. coli) dapat menyebabkan gangguan sistem hematologi, di antaranya berupa penurunan konsentrasi hemoglobin. Konsumsi probiotik dianggap sebagai salah satu upaya untuk meningkatkan sintesis hemoglobin. Penelitian ini bertujuan untuk mengetahui pengaruh Lactobacillus spp. terhadap konsentrasi hemoglobin pada tikus putih (Rattus norvegicus) yang diinduksi oleh lipopolisakarida (LPS) E. coli. Rancangan penelitian ini adalah true experimental dengan desain randomized post test only control group. Dua puluh satu ekor tikus putih dibagi ke dalam tiga kelompok yaitu: (1) kelompok tikus tanpa perlakuan sebagai kontrol negatif $(n=7)$, (2) kelompok tikus yang diinduksi LPS E. coli $(n=7)$, dan (3) kelompok tikus yang dipapar Lactobacillus spp. dan dinduksi LPS E. coli $(n=7)$. Konsentrasi hemoglobin diukur dengan metode oksihemoglobin. Hasil penelitian menunjukkan perbedaan konsentrasi hemoglobin antara kelompok tikus dengan paparan probiotik dan diinduksi LPS E. coli $(8,9 \pm 0,3 \mathrm{mmol} / \mathrm{L})$ dibandingkan dengan kelompok kontrol negatif $(8,0 \pm 0,8 \mathrm{mmol} / \mathrm{L})$, dan kelompok yang hanya diinduksi LPS $E$. coli $(8,4 \pm 0,5$ $\mathrm{mmol} / \mathrm{L})(p<0,05)$. Disimpulkan bahwa Lactobacillus spp. dapat meningkatkan konsentrasi hemoglobin pada tikus putih yang diinduksi LPS E. coli.
\end{abstract}

Kata kunci: hemoglobin, Lactobacillus spp., lipopolisakarida E. coli

\section{PROBIOTIC INCREASE HEMOGLOBIN CONCENTRATION IN RATS INDUCED BY LIPOPOLYSACCHARIDE OF ESCHERICHIA COLI}

\begin{abstract}
Infection caused by E. coli may lead to a hematological system disorder, such as decreasing of hemoglobin concentration. Consumption of probiotic was considered as an effort to improve hemoglobin synthesis. This study aimed to assess the effect of Lactobacillus spp. on hemoglobin concentration in rats (Rattus norvegicus) induced by lipopolysaccharide (LPS) of E. coli. A true experimental research with randomized post test only control group design was performed. Twenty one rats were divided into three groups including: (1) a negative control $(n=7),(2)$ a group was induced with LPS of $E$. coli $(n=7)$, and (3) a group was exposed to Lactobacillus spp. prior to induction by LPS of $E$. coli $(n=7)$. Hemoglobin concentration was measured by oxyhemoglobin method. The results showed the difference of hemoglobin concentration among groups of rat exposed to Lactobacillus spp prior to induction by LPS of $E$. coli $(8,9 \pm 0,3$ $\mathrm{mmol} / \mathrm{L})$, control negative group $(8,0 \pm 0,8 \mathrm{mmo} / \mathrm{L})$, and group of rat induced by LPS $E$. coli $(8,4 \pm 0,5 \mathrm{mmol} / \mathrm{L})$ $(p<0,05)$. It is concluded that Lactobacillus spp. can increase the hemoglobin concentration in rats induced by LPS of E. coli.
\end{abstract}

Keywords: E. coli lipopolysaccharide, hemoglobin, Lactobacillus spp.

* Jurusan Keperawatan, Fakultas Kedokteran Universitas Brawijaya

ఐE-mail: efriskartika@gmail.com atau efriskartika@ub.ac.id 


\section{Pendahuluan}

Infeksi yang disebabkan oleh bakteri Escherichia coli (E. coli) dapat berkembang menjadi sepsis. Data menunjukkan bahwa penyebab sepsis didominasi oleh bakteri gram negatif seperti $E$. coli dengan persentase $60-70 \% .{ }^{1}$ Angka kejadian sepsis meningkat hingga $13 \%$ per tahun, menjadi penyebab utama morbiditas dan mortalitas di negara maju dan negara berkembang. Diperkirakan 20-30 juta kasus sepsis terjadi terjadi di seluruh dunia, dengan lebih dari enam juta kasus sepsis neonatal dan seratus ribu kasus sepsis maternal. Angka kematian meningkat ketika pasien mengalami kondisi perburukan dari sepsis ke sepsis berat kemudian syok septik. ${ }^{2-4}$

Produk yang memiliki peranan penting dalam terjadinya sepsis tersebut adalah lipopolisakarida (LPS) yang merupakan komponen penting pada membran luar bakteri gram negatif. Lipopolisakarida mengikat protein spesifik dalam plasma yaitu lipopolysaccharide binding protein (LBP). Selanjutnya kompleks LPS-LBP ini akan berikatan dengan $\mathrm{CD} 14$, yaitu reseptor pada membran makrofag. CD14 akan mempresentasikan LPS kepada toll-like receptor 4 (TLR4) yaitu reseptor untuk transduksi sinyal sehingga terjadi aktivasi makrofag. Aktivasi makrofag akan melepaskan mediator inflamasi yang akan mengaktivasi sistem koagulasi dan sistem komplemen. Pada sistem koagulasi terjadi ketidakseimbangan antara sitokin proinflamasi dengan sitokin antiinflamasi yang merupakan karakteristik kondisi sepsis. $^{5}$

Kondisi inflamasi yang meluas akibat infeksi menyebabkan abnormalitas pada berbagai sistem organ, salah satunya adalah sistem hematologi. Fungsi sistem hematologi yaitu mendistribusikan nutrisi, oksigen serta zat-zat lain ke semua organ, sehingga memungkinkan organ tubuh melakukan fungsinya. Apabila fungsi hematologi terganggu, maka akan terjadi gangguan pada organ lain. ${ }^{6}$ Abnormalitas paling umum terjadi pada sistem hematologi pada kondisi infeksi adalah anemia, leukositosis, leukopenia, dan trombositopenia. Anemia merupakan masalah akut yang umum pada pasien yang terinfeksi bakteri. Ada banyak faktor yang menyebabkan anemia pada pasien tersebut yaitu tindakan plebotomi rutin, penurunan sintesis sel darah merah, peningkatan destruksi karena perubahan morfologi dan perubahan membran sel darah merah selama proses inflamasi. 7,8

Kondisi inflamasi yang meluas akibat infeksi bakteri terbukti meningkatkan lama perawatan (length of stay), biaya perawatan, morbiditas, dan mortalitas pasien. ${ }^{9}$ Upaya pencegahan dibutuhkan agar kondisi infeksi tidak meluas dan berkembang menjadi sepsis, serta menjaga agar parameter hematologi pasien tetap normal, yaitu dengan meningkatkan sistem kekebalan tubuh atau imunitas pasien. Salah satu upaya meningkatkan imunitas adalah dengan pemberian bakteri asam laktat (BAL) yang di isolasi menjadi probiotik. ${ }^{10}$

Bakteri Lactobacillus spp. yang termasuk dalam BAL mampu bertahan hidup dan berkembang biak, berkompetisi dengan bakteri jahat, serta mengeluarkan zat antibakteri dalam saluran pencernaan manusia (meningkatkan kekebalan tubuh) sehingga dapat menghambat pertumbuhan bakteri jahat. Probiotik diketahui dapat mempengaruhi imunitas tubuh dengan beberapa cara yaitu, merangsang peningkatan produksi antibodi dan meningkatkan integritas epitel, peningkatan signal $T L R$, interaksi sel dendrit dan sel $T$ serta meningkatkan asosiasi sel T.11-13 Walaupun target utama bakteri Lactobacillus sebagai probiotik adalah saluran pencernaan, namun beberapa penelitian membuktikan bahwa efek immunomodulator probiotik terhadap gambaran hematologi 
dapat dijelaskan secara sistematik. Penelitian oleh Astawan et al. (2011), pada kelompok tikus yang diinfeksi Enteropathogensis E. coli (EPEC) menunjukan bahwa kelompok tikus yang diberi diet probiotik memiliki jumlah sel darah merah yang lebih tinggi dibandingkan dengan kelompok tikus yang hanya diberi diet standar. Sementara pada penelitian Salahuddin et al. (2013), menunjukan bahwa terjadi perubahan yang signifikan pada parameter sel darah merah yaitu peningkatan jumlah eritrosit dan konsentrasi hemoglobin pada kelompok tikus yang diberikan diet probiotik dibandingkan dengan kelompok yang tidak mendapat diet probiotik. 6,14

Sebagian besar penelitian tentang pengaruh probiotik berfokus pada pencegahan dan terapi penyakit gastrointestinal, padahal probiotik memiliki potensi dalam mencegah perluasan infeksi dan berpengaruh pada konsentrasi hemoglobin. Oleh karena itu, penelitian ini bertujuan untuk mengetahui pengaruh probiotik (Lactobacillus spp.) terhadap konsentrasi hemoglobin pada tikus putih (Rattus norvegicus) yang mengalami inflamasi sistemik akibat induksi LPS E. coli.

\section{Bahan dan Metode}

Pembuatan kultur Lactobacillus spp.

Persiapan kultur probiotik Lactobacillus spp. dilakukan dengan medium MRS agar/MRS broth yang dilanjutkan dengan prosedur kultur Lactobacillus spp. Dilakukan sterilisasi ose lengkung dengan pemanasan di atas bunsen hingga pijar. Setelah ose dipastikan dingin bakteri Lactobacillus spp. diambil dari stok dengan cara menyentuhkan ujung ose pada stok, kemudian menggoreskannya pada permukaan media MRS-Agar, dengan metode streaking kuadran untuk mendapatkan koloni terpisah. Dilanjutkan dengan menginkubasikan media
$37{ }^{\circ} \mathrm{C}$ selama 24 jam. Koloni murni yang tumbuh diidentifikasi ulang untuk memastikan spesies bakteri. Setelah terbukti spesies Lactobacillus spp. dilakukan kultur pengayaan untuk memproduksi dalam jumlah yang besar, dan melakukan pengenceran sesuai dengan kepadatan bakteri yang diinginkan. ${ }^{15}$ Lactobacillus spp. diberikan dengan dosis $10^{9} \mathrm{CFU} / \mathrm{Kg} \mathrm{BB} /$ hari yang dilarutkan dalam media Dextrose $5 \%$ (D5\%) sebanyak 0,5 ml.

\section{Hewan Coba}

Hewan coba yang digunakan adalah tikus putih (Rattus norvegicus) galur Wistar yang berjumlah 21 ekor, dengan kriteria inklusi yaitu tikus sehat, jenis kelamin jantan, usia 10-12 minggu, berat badan 150-200 gram, sedangkan kriteria eksklusi yaitu tikus sakit dan mati dalam masa penelitian. Sebelum diberi perlakuan, hewan coba di aklimatisasi selama 7 hari dengan diberi makan dan minum secara ad-libitum. Penggunaan hewan coba sebagai subjek penelitian ini telah mendapatkan keterangan laik etik dari Komisi Etik Penelitian Kesehatan Fakultas Kedokteran Universitas Brawijaya (No. 362/EC/KEPK/09/2016).

\section{Induksi LPS E. coli}

Induksi LPS E. coli (List Biological, nomor katalog 201) dilakukan per oral. LPS diencerkan dengan larutan $\mathrm{NaCl} \quad 0,9 \%$ dengan perbandingan $\mathrm{NaCl}$ 0,9\%:LPS E. coli yaitu 10:1. Dosis yang diberikan yaitu 1 $\mathrm{mg} / \mathrm{KgBB}$ yang dilarutkan dalam media $\mathrm{NaCl}$ $0.9 \%$ sebanyak $0,5 \mathrm{ml}$. ${ }^{16,17}$

\section{Desain Penelitian}

Rancangan yang digunakan pada penelitian ini adalah true experimental dengan desain randomized post test only control group. Sejumlah 21 ekor tikus dibagi secara acak ke dalam 3 kelompok sebagai berikut: kelompok tikus tanpa perlakuan apapun sebagai kontrol negatif $(n=7)$; 
kelompok tikus yang diinduksi LPS E. coli $(\mathrm{n}=7)$ dengan dosis $1 \mathrm{mg} / \mathrm{kg} \mathrm{BB}$ pada hari ke 15; dan kelompok tikus yang diberi probiotik Lactobacillus spp. $\quad\left(10^{9}\right.$ $\mathrm{CFU} / \mathrm{KgBB} /$ hari selama 14 hari $^{18}$, dan diinduksi LPS E. coli $(n=7)$ dengan dosis 1 $\mathrm{mg} / \mathrm{kg}$ BB pada hari ke-15.

\section{Pengukuran Konsentrasi Hemoglobin}

Pengambilan sampel darah intra cardiac dilakukan pada hari ke-16 (24 jam setelah induksi LPS E. coli). Sampel darah diambil sebanyak $1 \mathrm{ml}$, kemudian ditampung dalam tabung yang mengandung EDTA. Analisis konsentrasi hemoglobin dilakukan segera setelah pengumpulan sampel darah. ${ }^{19}$

Konsentrasi hemoglobin dihitung dengan metode oksihemoglobin. Sejumlah 5 ml larutan Na-Karbonat 0,1\% dimasukan ke dalam tabung reaksi, kemudian ditambahkan EDTA $20 \mu$ l. Selanjutnya tabung reaksi ditutup dan dikocok selama 10 detik. Serapan dibaca dengan spektrofotometer pada $540 \mathrm{~nm}$. Pembacaan konsentrasi hemoglobin dilakukan pada kuvet kalibrasi yang telah dipersiapkan sebelumnya.

\section{Analisis Statistik}

Data disajikan sebagai nilai ratarata \pm standar deviasi (SD). Analisis statistik dilakukan dengan menggunakan program IBM SPSS 2.0. Uji one way anova dilakukan untuk mengetahui pengaruh pemberian probiotik terhadap konsentrasi hemoglobin darah tikus putih pada setiap kelompok, yang dilanjutkan dengan uji post hoc Tukey.

\section{Hasil}

Hasil analisis statistik nilai rata-rata konsentrasi hemoglobin pada kelompok tikus normal, kelompok tikus yang diinduksi LPS E. coli, dan kelompok tikus yang diberi probiotik dan diinduksi LPS E. coli tercantum pada Tabel 1. Hasil pengukuran hemoglobin memperlihatkan bahwa nilai rata-rata konsentrasi hemoglobin ketiga kelompok tikus berbeda secara nyata $(p=0,025)$. Kelompok tikus yang tidak mendapatkan perlakuan/kontrol negatif memiliki konsentrasi hemoglobin yang terendah $(8,0 \pm$ $0,8 \mathrm{mmol} / \mathrm{L})$, diikuti dengan nilai rata-rata konsentrasi hemoglobin kelompok tikus yang diinduksi LPS E. coli $(8,4 \pm 0,5 \mathrm{mmol} / \mathrm{L})$, sedangkan kelompok tikus yang diberi probiotik dan diinduksi LPS E. coli memiliki konsentrasi hemoglobin paling tinggi $(8,9 \pm 0,3 \mathrm{mmol} / \mathrm{L})$.

Hasil uji post hoc Tukey tercantum pada Tabel 2.

Tabel 1. Nilai rata-rata konsentrasi hemoglobin pada kelompok hewan coba

\begin{tabular}{|c|c|c|c|}
\hline Kelompok & $\begin{array}{l}\text { Rata-rata Konsentra } \\
(\mathrm{mmol} / \mathrm{L})\end{array}$ & $\mathrm{Hb} \pm \mathrm{SD}$ & \\
\hline Kontrol negatif $(n=7)$ & $8,0 \pm 0,8$ & & \\
\hline Induksi LPS E. coli $(\mathrm{n}=7)$ & $8,4 \pm 0,5$ & & \\
\hline Probiotik dan Induksi LPS E. coli $(n=7)$ & $8,9 \pm 0,3$ & & \\
\hline \multicolumn{4}{|c|}{ Tabel 2. Hasil uji post hoc Tukey konsentrasi hemoglobin pada kelompok hewan coba } \\
\hline Faktor (I) & Faktor $(\mathrm{J})$ & Mean Difference (I-J) & p \\
\hline \multirow[t]{2}{*}{ Kontrol negatif } & Induksi LPS E. coli & $-0,4$ & 0,351 \\
\hline & Probiotik dan Induksi LPS E. coli & $-0,9$ & 0,020 \\
\hline \multirow[t]{2}{*}{ Induksi LPS E. coli } & Konrol negatif & 0,4 & 0,351 \\
\hline & Probiotik dan Induksi LPS E. coli & $-0,5$ & 0,275 \\
\hline Probiotik dan Induksi LPS E. coli & Kontrol negatif & 0,9 & 0,020 \\
\hline
\end{tabular}


Hasil uji post hoc Tukey menunjukan terdapat perbedaan nilai rata-rata konsentrasi hemoglobin yang bermakna pada kelompok yang diberi probiotik dan diinduksi LPS E. coli dibandingkan dengan kelompok kontrol negatif.

\section{Pembahasan}

Hemoglobin adalah komponen yang berfungsi sebagai alat transportasi oksigen dan karbondioksida. Satu gram hemoglobin mengangkut 1,34 $\mathrm{ml}$ oksigen. Kapasitas angkut ini berhubungan dengan kadar hemoglobin, bukan jumlah sel darah merah. Penetapan anemia didasarkan pada nilai hemoglobin yang berbeda secara individual karena berbagai adaptasi tubuh (misalnya ketinggian, penyakit paru-paru, olahraga). Secara umum, jumlah hemoglobin kurang dari 7,4 mmol/L menunjukkan anemia. Pada penentuan status anemia, jumlah total hemoglobin lebih penting daripada jumlah eritrosit. 20

Hemoglobin merupakan komponen yang berfungsi sebagai alat transportasi oksigen dan karbondioksida. Pada kondisi infeksi sistemik $E$. coli yang berpotensi dilepaskannya LPS sehingga terjadi inflamasi sistemik dan mengalami penurunan konsentrasi hemoglobin. Penelitian ini bertujuan untuk mengobservasi pengaruh pemberian probiotik terhadap konsentrasi hemoglobin dalam kondisi mengalami inflamasi sistemik karena induksi LPS E coli. Untuk itu, dibuat kelompok tikus yang diinduksi LPS $E$. coli yang menggambarkan keadaan inflamasi sistemik bila individu mengalami infeksi bakteri E.coli.

Hasil pengukuran konsentrasi hemoglobin pada kelompok tikus yang diinduksi LPS E. coli adalah $8,4 \pm 0,5 \mathrm{mmol} / \mathrm{L}$, lebih tinggi daripada kelompok tikus kontrol negatif $(8,0 \pm 0,8 \mathrm{mmol} / \mathrm{L})$. Pemberian LPS akan menyebabkan peningkatan respons imun sitokin proinflamasi, dan menekan respons antiinflamasi. Ketika respons proinflamasi telah mencapai puncak, keseimbangan akan bergeser ke respons imun sitokin antiinflamasi. Pengaruh pemberian LPS terhadap respons imun tergantung pada dosis yang diberikan. Pemberian dosis rendah $\pm 100 \mu \mathrm{g} / \mathrm{ml}$ akan menyebabkan respons imun proinflamasi yang mencapai nilai maksimal pada 12 jam setelah pemberian, sedangkan LPS dosis tinggi $\pm 1000 \mu \mathrm{g} / \mathrm{ml}$ akan memberikan efek maksimal pada 24 jam setelah pemberian LPS. ${ }^{21}$ Kondisi inflamasi yang meluas berhubungan dengan peningkatan destruksi karena perubahan pada membran sel darah merah dan interaksi dengan sel darah putih serta aktifitas sitokin. Kondisi inflamasi dicirikan dengan adanya peningkatan produksi reactive oxygen species (ROS) diikuti dengan penurunan pertahanan terhadap antioksidan. ROS yang mengandung superoksida anion $\mathrm{O}_{2}$, hydroxyl radical $\mathrm{OH}^{-}$dan hidrogen peroxide $\mathrm{H}_{2} \mathrm{O}_{2}$, menyebabkan kerusakan pada hemoglobin dan menginduksi hemolisis. 7,22 Hal tersebut mengakibatkan penurunan konsentrasi hemoglobin pada kondisi sepsis.

Pada kelompok tikus yang diberi probiotik dan diinduksi LPS E. coli, dan kelompok tikus yang diinduksi LPS E. coli saja, menunjukkan tikus mengalami kondisi inflamasi sistemik. Kondisi inflamasi luas dapat menyebabkan hemolisis sehingga menyebabkan hemoglobin keluar ke ekstraseluler sebagai hemoglobin bebas yang bersifat toksik dan penurunan kemampuan transport oksigen. Namun, hasil penelitian tidak menunjukkan penurunan konsentrasi hemoglobin (anemia) pada kelompok yang diinduksi $E$. coli, yang kemungkinan disebabkan belum terjadi hemolisis pada saat pengambilan sampel 
darah, yaitu 24 jam setelah induksi LPS $E$. coli.

Hasil penelitian ini berbeda dengan penelitian oleh Jansma et al. (2013), yang bertujuan mengobservasi perbedaan konsentrasi hemoglobin pada pasien dengan sepsis fase akut dan pasien yang tidak mengalami sepsis di ruang rawat intensif. Jansma mendapatkan konsentrasi hemoglobin pada pasien yang mengalami infeksi bakteri sistemik (sepsis) fase akut lebih rendah daripada pasien yang tidak mengalami sepsis. ${ }^{23}$ Perbedaan tersebut terjadi kemungkinan karena subjek sepsis mengalami inflamasi sistemik akibat infeksi bakteri, tidak hanya inflamasi akibat induksi LPS. Selain itu, pada penelitian tersebut subjek sepsis telah mengalami hemolisis

Dugaan adanya pengaruh pemberian probiotik sebelum paparan LPS $E$. coli sebagai upaya preventif terjadinya penurunan konsentrasi hemoglobin akibat infeksi dapat dilihat pada kelompok tikus yang diberi probiotik dan diinduksi LPS $E$. coli. Hasil penelitian menunjukkan nilai ratarata konsentrasi hemoglobin pada kelompok probiotik adalah $8,9 \pm 0,3 \mathrm{mmol} / \mathrm{L}$. Konsentrasi hemoglobin kelompok yang diberi probiotik dan diinduksi LPS E. coli memiliki nilai lebih tinggi secara bermakna dibandingkan dengan kelompok tikus kontrol negatif, yang artinya terdapat pengaruh pemberian probiotik antara kelompok tikus yang diberi probiotik dan diinduksi LPS $E$. coli jika dibandingkan dengan kelompok tikus kontrol negatif.

Tingginya konsentrasi hemoglobin pada kelompok tikus yang diberi probiotik dan diinduksi LPS E. coli berhubungan dengan mekanisme biosintesis aktif hemoglobin sehingga meningkatkan konsentrasi hemoglobin intraselular. Fungsi probiotik dalam pembentukan sel darah merah dan hemoglobin berkaitan dengan pemenuhan vitamin B. Asam folat dan vitamin B12 penting dalam pematangan akhir sel darah merah. Keduanya berperan dalam pembentukan timidin trifosfat, yait zat pembangun essensial DNA. Kekurangan asam folat dan vitamin B12 menyebabkan abnormalitas, kegagalan pematangan inti dan pembelahan sel. Folat terlibat penting dalam metabolisme sel seperti replikasi DNA, perbaikan dan metilasi serta sintesis nukleotida, vitamin dan beberapa asam amino. Kekurangan folat terutama menyebabkan gangguan metabolisme DNA yang mengakibatkan perubahan morfologi sel terutama sel-sel yang sangat cepat membelah seperti sel darah merah, sel darah putih, serta sel epitel lambung dan usus. Cobalamin atau vitamin B12 merupakan satu-satunya vitamin yang disintesis oleh mikroorganisme dan hanya beberapa bakteri yang memiliki kemampuan untuk memproduksinya serta kebanyakan terdapat pada makanan yang berasal dari hewan seperti daging, ikan, dan telur. ${ }^{24-26}$

Pemberian probiotik menyebabkan terjadinya biosintesis aktif hemoglobin dan peningkatan hemoglobin intraseluler, sehingga konsentrasi hemoglobin lebih tinggi pada kelompok probiotik dibandingkan dengan kelompok normal. Pemberian probiotik mampu melindungi epitel usus dari kerusakan akibat infeksi mikroba sehingga mengoptimalkan penyerapan zat besi $(\mathrm{Fe})$, dan mengoptimalkan pemenuhan vitamin B12 dan asam folat yang penting dalam pembentukan dan pematangan sel darah merah dan hemoglobin. Hasil ini didukung oleh hasil penelitian Salahuddin et al. (2013) dan Astawan et al. (2011) yang menunjukan bahwa terdapat perbedaan konsentrasi hemoglobin yang bermakna antara kelompok yang diberi diet probiotik dibandingkan dengan kelompok yang tidak diberi diet probiotik. 6,14

Keterbatasan penelitian ini adalah tidak melakukan pemberian probiotik dengan dosis yang berbeda untuk melihat perbedaan respons imun dan perbedaan 
respons pemenuhan nutrisi untuk pembentukan hemoglobin. Selain itu, pemeriksaan konsentrasi hemoglobin hanya dilakukan 24 jam setelah induksi LPS E.coli, tidak dilakukan pada waktu yang berbeda atau time series mengingat ekspresi sitokin dan respons imun tertentu dapat dipengaruhi waktu dan berperan besar dalam hemolisis. Saran untuk penelitian selanjutnya, hendaknya dilakukan pemberian probiotik dengan dosis berbeda, dengan pemeriksaan konsentrasi hemoglobin dalam waktu berbeda (time series) untuk melihat respons pemberian probiotik terhadap konsentrasi kemoglobin pada tikus putih yang diinduksi LPS E. coli.

\section{Kesimpulan}

Hasil penelitian ini menunjukkan bahwa probiotik (Lactobacillus spp.) berpengaruh terhadap tingginya konsentrasi hemoglobin pada tikus putih (Rattus norvegicus) yang diinduksi LPS E. coli.

\section{Ucapan Terima Kasih}

Kami mengucapkan terima kasih kepada Badan Penelitian dan Pengabdian Masyarakat Fakultas Kedokteran Universitas Brawijaya yang membantu pendanaan penelitian ini.

\section{Daftar Pustaka}

1. Guntur H, Sudoyo AW, Setiyohadi B, Alwi I, Simadibrata M, Setiati S. Buku Ajar IImu Penyakit Dalam. Jilid Ke-3. Edisi Ke11. Jakarta: Pusat Penerbitan IImu Penyakit Dalam Fakultas Kedokteran Universitas Indonesia. 2010.

2. Bhagwanjee S, Reinhart K. How Do We Deal with Sepsis in The Twenty First Century?. Clinical Governance. 2013; 18:58-62.
3. Black RE, Cousens S, Johnson HL, Lawn JE, Rudan I, Bassani DG. Global, Regional, and National Causes of Child Mortality in 2008: A Systematic Analysis. The Lancet. 2010; 375(9730):1969-87.

4. Kissoon N, Carcillo JA, Espinosa V, Argent A, Devictor D, Madden M. World Federation of Pediatric Intensive Care and Critical Care Societies: Global Sepsis Initiative. Pediatric Critical Care Medicine. 2011; 12(5):494-503.

5. Elena GR, Alejo C, Gema R, Mario D. Cortistatin, a New Antiinflammatory Peptide with Therapeutic Effect on Lethal Endotoxemia. Journal of Experimental Medicine. 2006; 203(3):563-71.

6. Astawan M, Wresdiyati T, Arief I, Suhesti E. Gambaran Hematologi Tikus Puth (Rattus norvegicus) yang Diinfeksi Escherichia coli Enteropatogenik dan Diberikan Probiotik. Media Peternakan. 2011; 34(1):7-13.

7. Piagnerelli M, Boudjeltia KZ, Gulbis B, Vanhaeverbeek M, Vincent JL. Anemia in Sepsis: The Importance of Red Blood Cell Membrane Changes. Transfusion Alternatives in Transfusion Medicine. 2007; 9:143-9.

8. Sadaka F. Red Blood Cell Transfusion in Sepsis: A Review. Journal of Blood Disorders \& Transfusion. 2013; 4(4):1-7.

9. Crooks NH, Snaith C, Webster D, Gao F, Hawkey P. Clinical review: Probiotics in critical care. Critical Care. 2012; 16:237.

10. Sarowska J, Choroszy-Król I, RegulskaIlow B, Frej-Mądrzak M, Jama-Kmiecik A. The Therapeutic Effect of Probiotic Bacteria on Gastrointestinal Diseases. Advances in Clinical and Experimental Medicine. 2013; 22(5):759-66.

11. Barraud D, Blard C, Hein F, Marcon O, Cravoisy Al, Nace $\mathrm{L}$, et al. Probiotics in The Critically III Patient: A Double Blind, Randomized, Placebo-Controlled Trial. Intensive Care Med. 2010; 36:1540-7. 
12. Shlomai NO, Deshpande G, Rao S, Patole S. Probiotics for Preterm Neonates: What Will It Take to Change Clinical Practice?. Neonatology. 2013; 105(1):64-70.

13. Qadis AQ, Goya S, Yatsu M, Yoshida YU, Ichijo T, Sato S. Effects of a Bacteria-Based Probiotic on Subpopulations of Peripheral Leukocytes and Their Cytokine mRNA Expression in Calves. Journal of Veterinary Medical Science. 2014; 76(2):189-95.

14. Salahuddin M, Akhter H, Akter S, Miah MA, Ahmad N. Effects of Probiotics on Haematology and Biochemical Parameters in Mice. Bangladesh Veterinarian. 2013; 30(1):20-4.

15. Goyal R, Dhingra H, Bajpai $P$, Joshi N. Characterization of the Lactobacillus Isolated from Different Curd Samples. African Journal of Biotechnology. 2012; 11(79):14448-52.

16. Couper K, Blount D, Riley E. IL-10: The Master Regulator of Immunity to Infection. The Journal of Immunology. 2008; 180:5771-7.

17. Popov D, Pavlov G. Sepsis Models in Experimental Animals. Trakia Journal of Sciences. 2013; 1:13-23.

18. Sarowska J, Choroszy-Król I, RegulskaIlow $B$, Frej-Mądrzak M, Jama-Kmiecik $A$. The Therapeutic Effect of Probiotic Bacteria on Gastrointestinal Diseases. Advances in Clinical and Experimental Medicine. 2013; 22(5):759-66.

19. Fahrimal $Y$, Eliawardani, Rafina $A, A z h a r$ A, Asmilia N. Profil Darah Tikus Putih (Rattus norvegicus) yang Diinfeksikan Trypanosoma evansi dan Diberikan
Ekstrak Kulit Batang Jaloh (Salix tetrasperma Roxb). Jurnal Kedokteran Hewan. 2014; 8(2):164-8.

20. Herawati $F$, Andrajati $R$, Umar $F$. Pedoman Interpretasi Data Klinik. Indonesia KKR (Editor). Jakarta: Kementerian Kesehatan Republik Indonesia. 2011.

21. Larsson $R$, Rocksen D, Lilliehook $B$, Jonsson A, Bucht A. Dose-dependent Activation of Lymphocytes in Endotoxininduced Airway Inflammation. Infection and Immunity. 2000; 68:6962-9.

22. Adamzik $M$, Hamburger $T$, Petrat $F$, Peters J, Groot Hd, Hartmann M. Free Hemoglobin Concentration in Severe Sepsis: Methods of Measurement and Prediction of Outcome. Critical Care. 2012; 16(4):R125.

23. Jansma $G$, Buter $H$, Gerritsen RT, Boerma EC. Is Hemoglobin Concentration Affected by Sepsis in The Acute Phase?. Critical Care. 2013; 17(Suppl 2):10.

24. Muwakdiah. Efek Sumpelemntasi Fe, Asam Folat dan Vitamin B12 terhadap Peningkatan Kadar $\mathrm{Hb}$ pada Wanita Pekerja di Kabupaten Sukoharjo. Semarang: Universitas Diponegoro. 2009.

25. Capozzi V, Russo P, Dueñas MT, López $P$, Spano G. Lactic Acid Bacteria Producing B-group Vitamins: A Great Potential for Functional Cereals Products. Applied Microbiology and Biotechnology. 2012; 96(6):1383-94.

26. Stabler SP. Vitamin B12 Deficiency. New England Journal of Medicine. 2013; 368(2):149-60. 